\title{
Collaborative governance: The antidote for effective implementation of malaria elimination programme in Nigeria
}

\author{
*Taleat B.A. ${ }^{1}$, Olawoyin K.W. ${ }^{2}$
}

\begin{abstract}
Objective: The study examined the way inter-governmental collaboration can be improved to enhance malaria elimination programme in Southwestern Nigeria.
\end{abstract}

Methodology: Primary data were collected through the administration of questionnaire and conduct of interviews. The study population comprised all categories of staff in the National Malaria Elimination Programme; staffs of Malaria Elimination Programme in three states and nine Local Governments in Southwestern Nigeria. A sample size of 388 respondents was selected for questionnaire administration from the study population. Interviews were conducted to complement information collected through questionnaire. Data collected were analysed using appropriate statistical methods.

Results: The study revealed that increased allocation of funds; establishment of several anti-malaria programmes at all levels of government and integrated decision making were ways collaborative governance can be improved to enhance malaria elimination programme in the study area.

Conclusion: The study concluded that collaborative governance is a sine qua non to the effective implementation of government programmes.

Keywords: Collaboration, Governance, Implementation, Malaria, Programmes

\section{*Corresponding author}

Taleat B.A

ORCID-NO: http://orcid.org/0000-0003-4745-095X

Email: abioduntaleat@gmail.com

\footnotetext{
${ }^{1}$ Department of Public Administration, Faculty of Administration, Obafemi Awolowo University, Ile-Ife, Nigeria.

${ }^{2}$ Department of Political Science and International Relations, Faculty of Social Sciences, Osun State University, Osogbo, Nigeria.
} 


\title{
Gouvernance collaborative: L'antidote pour une mise en œuvre efficace du programme d'élimination du paludisme au Nigéria
}

\author{
*Taleat B.A. ${ }^{1}$, Olawoyin K.W. ${ }^{2}$
}

Résumé

Objectif de l'étude: L'étude a examiné la manière dont la collaboration intergouvernementale peut être améliorée pour améliorer le programme d'élimination du paludisme dans le sud-ouest du Nigeria.

Méthode de l'étude : Les données primaires ont été recueillies par l'administration d'un questionnaire et la conduite d'entretiens. La population étudiée comprenait toutes les catégories de personnel du programme national d'élimination du paludisme ; le personnel du programme d'élimination du paludisme dans trois états et neuf gouvernements locaux du sud-ouest du Nigéria. Un échantillon de 388 répondants a été sélectionné pour l'administration du questionnaire à partir de la population étudiée. Des entretiens ont été menés pour compléter les informations recueillies par questionnaire. Les données recueillies ont été analysées à l'aide de méthodes statistiques appropriées.

Résultat de l'étude : L'étude a révélé que l'augmentation de l'allocation des fonds; la mise en place de plusieurs programmes antipaludiques à tous les niveaux de gouvernement et la prise de décision intégrée étaient des moyens d'améliorer la gouvernance collaborative pour améliorer le programme d'élimination du paludisme dans la zone d'étude.

Conclusion : L'étude a conclu que la gouvernance collaborative est une condition sine qua non à la mise en œuvre efficace des programmes gouvernementaux.

Mots-clés : Collaboration, gouvernance, mise en œuvre, paludisme, programmes

\author{
*Corresponding author \\ Taleat B. A \\ ORCID-NO: http://orcid.org/0000-0003-4745-095X \\ Email: abioduntaleat@gmail.com

\footnotetext{
${ }^{1}$ Department of Public Administration, Faculty of Administration, Obafemi Awolowo University, Ile-Ife, Nigeria. ${ }^{2}$ Department of Political Science and International Relations, Faculty of Social Sciences, Osun State University, Osogbo, Nigeria.
}

Research Journal of Health Sciences subscribed to terms and conditions of Open Access publication. Articles are distributed under the terms of Creative Commons Licence (CC BY-NC-ND 4.0). (http://creativecommons.org/licences/by-nc-nd/4.0)

http://dx.doi.org/10.4314/rejhs.v9i4.7 


\section{INTRODUCTION}

The mode of Nigeria healthcare system is categorised as tripartite in nature, viz: the tertiary, secondary and primary healthcare (1). The Nigerian Constitution gave room for collaborative governance as it provides each tier of government with substantial autonomy to carry out public assignments. In view of this, the technique for effective collaboration for the implementation of malaria programme should be one of the the most concern and crucial matters in Nigeria public health system, the reason being that malaria endemic serves as one of the keen issues affecting the public health which necessitates a concentrated effort by all levels of government. It is pertinent to say that, the health sector is one of the indispensable institutions in any country, it requires the needs to constitute a viable institutional structure with efficient collaboration to manage and implement health policies and programmes.

The form of collaborative governance to eliminate malaria needs to be re-evaluated, owing to the general belief that all tiers of government are concomitantly assigned the responsibilities for the management of healthcare services delivery (2). The health authourity at the national level is constitutionally empowered to collaborate legitimately with all levels of government in an effort to sustain national programmes on health (3). However, government at all levels seems to have failed in the accomplishment of some of the objectives of health programmes and policies. The failure emanated from a lack of viable collaboration among all levels of public health institutions (4). Governments also failed because of inadequate evaluation of responsibilities and identification of exclusive roles among them (5).

The Ministry of health at the Federal level (FMOH) is in charge of tertiary healthcare system throughout the federation. Government at the state level have Ministry of Health (SMOH) in care of health services at the secondary level. Although, some states also operates teaching hospitals but categorized as secondary system. Meanwhile, Local Government Area has Local Government Health Department operating a primary healthcare system through the support from state ministries of health. Nevertheless, the roles and responsibilities of Primary Healthcare with respect to policies and programme implementation is evidently provided in the National Primary Health Care Development Act, establishing its functions, but these functions seems to be encroached by the state government.
This encroachment of roles and responsibilities of the lower level of government often result in overlapping of roles and responsibilities, duplication of efforts and resources wastages or even total neglect (6).

The FMOH reported that malaria is highly endemic in Nigeria as well as most subSaharan Africa; it menace caused the majority of health challenge with the increase in the level of attendant mortality and morbidity, and a contributory factor to the decline in human productivity and socio-economic development (7). The vulnerable populace is commonly the pregnant women and children under the age of five (8). This assertion prompted the Nigerian government to intensify and made a significant effort in an attempt to reduce ill-health and death caused by malaria to improve the standard of life of Nigerians through the introduction of a programme to control or rather eliminate malaria. The final report of Nigeria Malaria Indicator Survey 2015, revealed that since the year 2000, Governments at all levels adopted effective strategies to control malaria through the National Strategic Plans: 2001 - 2005, 2006 - 2010 and $2009-2013$. However, the incidence of malaria is still highly endemic in Nigeria, characterising Nigeria as a country with one of the highest global burden of malaria. Hence, this necessitates the 2014-2020 strategic plan (9).

In responding to malaria prevalence, the Nigerian government had strived towards eliminating malaria and rebranding the National Malaria Control Programme (NMCP) to National Malaria Elimination Programme (NMEP) (9). However, it is not an understatement to say that in spite of government and health partners' effort to eliminate malaria in Nigeria, small proportion of Nigerians populace are yet to access malaria prevention materials and treatment, leading to increase in deaths rate among the poor citizens. This statement could be substantiated in the affirmation of USAID, where it was revealed that Nigeria reported more than 7.8 million confirmed cases of malaria in 2014 and more than 6,000 malaria-related deaths, as well as 21 percent of deaths among children under five years of age (10).

However, there is no doubt that there had been increased efforts to eliminate malaria in Nigeria, but the transition from malaria control programme to elimination demands a paradigm shift in governance and requires a multi-sectorial approach. Indeed, there exist numerous scholarly effort on malaria control and studies on collaborative governance as distinct concepts and 
variables, but these studies divergently focused on the core area of the Nigerian health system. Considerably, these scholars examined malaria related cases, methods and strategies adopted to control malaria, peoples participation to manage malaria cases, effects and consequences of malaria endemic amongst several scholarly efforts that are contributory to the understanding of the menace caused by malaria endemic in Nigeria, the African continent and the world over (11-19).

Existing studies failed to evaluate the collaborative governance and collective roles of government authorities to control malaria, neither did they take cognizance of the conceptual elucidation in distinguishing the pattern of collaboration among the governmental authourity. Perceptively, they barely focused on micro aspects of collaborative governance, like; the activities of government institutions, health organisations and development at diverse governmental levels. Therefore, this deficient assessment of collaborative governance requires a critical enquiry into the pattern of intergovernmental collaboration with reference to collective activities of governments on malaria programme implementation in Southwestern zone of Nigeria; hence, necessity the present study.

\section{MATERIALSAND METHODS}

Primary and Secondary data were utilised for this study. Primary data were collected through the administration of questionnaire and conduct of in-depth interviews. This study was carried out in Southwestern Nigeria, which was delimited to a manageable scope of three States and nine Local Government Areas (LGAs) using a multi-stage sampling technique. At the first stage, Southwestern Nigeria was stratified into three axes, i.e Lagos/Ogun, Oyo/Osun and Ondo/Ekiti States due to their geographical closeness. At the second stage, Ogun, Osun and Ondo states were purposively selected from the three axes respectively. At the third stage, one LGA was selected from each of the three senatorial districts in the three selected states for the study using simple random sampling technique, making a total of nine LGAs. The study population of 404 comprised all the categories of staff from the National Malaria Elimination Programme, Ogun State Malaria Elimination Programme MEP, Ondo State MEP, Osun State MEP, Ifo Local Government Malaria Elimination Programme LGMEP, Odogbolu LGMEP, Ado-Odo Ota
LGMEP, Owo LGMEP, Odigbo LGMEP, Idanre LGMEP, Irepodun LGMEP, Ife-North LGMEP and Irewole LGMEP. These respondents were targeted because they are considered to be knowledgeable and at a vantage position to give useful information on the activities of government on malaria elimination programme in the study area. A sample size of 388 respondents was selected for questionnaire administration from the study population, using Taro Yemane sample size formula.

That is: $\mathrm{n}=\frac{\mathrm{N}}{\left(1+\overline{\mathrm{N}(\mathrm{e})^{2}}\right)}$

Where:

$\mathrm{n}$ - Signifies the sample size

$\mathrm{N}$ - Signifies the population under study

e - Signifies the margin error (it could be 0.10 , 0.05 or 0.01 )

In addition, interviews were conducted through face to face method with one Project Manager in each of the three selected States Malaria Elimination Programme and one Malaria Officer heading LGMEP in the nine selected LGAs; so as to complement information collected through questionnaire administration. Secondary data were obtained from textbooks, academic journals, the Internet, and official documents of the Ministry of Health on malaria programme. Data collected were analysed using EPIData and SPSS for the frequency and content analysis methods.

Consequently, a total of three hundred and eighty-eight (388) copies of questionnaire were administered to the above-mentioned category of respondents in order to elicit information on "collaborative governance and malaria elimination programme in southwestern Nigeria. Three hundred and sixty-three (363) copies of questionnaire were appropriately retrieved from the field, thus representing $93.6 \%$ of the total administered questionnaires. The section also presents the analysis of the quantitative data using SPSS which was presented in percentage, frequency while interview responses were also presented and finally discussed the findings of the study.

Ethical approval was obtained from the Health Research Ethic Committee (HREC), Institute of Public Health, Obafemi Awolowo University, Ile-Ife, Nigeria. (Reference number IPH/OAU/12/857). Verbal informed consent was ensured from all the Programme Managers in the three selected states and with all Malaria Officers in the nine Local Government Areas. No names 
were reported on the findings so as to ensure confidentiality.

\section{RESULTS}

This section presents data analysis and interpretation of the respondents' views on ways inter-governmental collaboration among the governments can be improved to enhance malaria programme in Southwestern Nigeria. Table I, reveals the demographic data of respondence while Table II, reveals frequency and percentage distribution of respondents on each of the assertions set out to achieve the study objective. The values/responses were organised using a likert scale of measurements.

In the first assertion as shown in Table II, 332 respondents, constituting $69.7 \%$ strongly agreed and 79 respondents, representing $21.8 \%$ agreed that increased allocation of funds for both state and local governments will enhance malaria prevention/elimination interventions in urban and rural households. Another $3(0.8 \%)$ disagreed and just $4(1.1 \%)$ strongly disagreed with the assertion, while 15 (4.1\%) made no response to this assertion.

It was however asserted whether there is the availability of appropriate anti-malaria medicines and commodities at all levels of healthcare facilities. Reacting to this second assertion, a larger percentage of the respondents fell in the agreement category as 270 (74.4) strongly agreed and $75(20.7 \%)$ agreed to the assertion. However, just 4 representing 1.1\% ordinarily disagreed with this assertion and strong disagreement was also of the same percentage of respondents. It could, therefore, be affirmed that appropriateness and availability of anti-malaria medicines are largely acknowledged to be evident or available at respective levels of healthcare facilities within the study area.

With regard to the third assertion, 213 respondents, representing $58.7 \%$ strongly agreed and 116 respondents, constituting 32\% agreed that there exists establishment of several antimalaria programmes targeted towards the improvement of the quality of life of the people by all levels of government. Against this, 3 respondents, representing $0.8 \%$ disagreed and 15 respondents, constituting $4.1 \%$ strongly disagreed, and $3(0.8 \%)$ of the respondents did not respond to this assertion. It then follows that improvement of health life of the people remains so cardinal to the enactment and operation of antimalaria programme within the study area.

On the fourth assertion in Table II, 164 $(45.2 \%)$ strongly agreed and $93(25.6 \%)$ agreed to the statement that there is effective referral system on complicated malaria cases from primary to secondary and to tertiary healthcare facilities. On aggregate, $70.8 \%$ of respondents tended towards agreement with this assertion. This indicates that operational evidence of collaborative governance was obtainable through the organised referral system for the control of malaria epidemic in Southwestern Nigeria.

An assertion was raised as to whether there are adequate and qualified health workers with unified and indiscriminate salary structure to all levels of health personnel. Responding to this fifth assertion, 129 (35.5\%) strongly agreed and $158(43.5 \%)$ agreed to this assertion. On the contrary, $13(3.6 \%)$ disagreed and $22(6.1 \%)$ strongly disagreed.

Eradication of marginalisation at all levels of government was assumed to be one of the ways through collaborative governance could be enhanced. Regarding this sixth assertion, 163 respondents, representing $44.9 \%$ strongly agreed and 111 respondents, constituting $30.6 \%$ agreed. In deviance, about 54 respondents, representing $14.9 \%$ disagreed and 27 respondents, constituting $7.4 \%$ strongly disagreed with this assertion, while 4 respondents, representing $1.1 \%$ did not react to this assertion. The interpretation of this data distribution is simply that the eradication of marginalisation among the tiers of government would reasonably bring about significant improvement in the implementation of malaria programme within the study area.

It was also opined whether harmonisation of relationships among health workers at all levels could enhance some improvements for the implementation of the malaria programme amidst other healthcare services. Reacting to this seventh assertion, 203 respondents, representing $55.9 \%$ strongly agreed and 124 respondents, constituting $34.2 \%$ agreed. Nevertheless, it could be deduced from an approximately $90 \%$ agreement level that greater sense of purpose and responsibility could be enhanced through harmonisation of relationships among health workers at all levels.

With respect to the eighth assertion, a total of 317 , representing $87.4 \%$ of the respondents credited the statement that integrated decision-making process is one of the ways through which Inter-governmental collaboration could enhance the implementation of malaria programme. However, this does not have absolute implication because there are pockets of respondents equating to $10.7 \%$ who disagreed 
with this statement; while about $0.8 \%$ of the respondents did not react to the statement. Hence, there is a clear indication that an integrated framework for decision making in the health sector has the capacity to drive the implementation process of malaria programme within the study area, and Nigeria as a whole.

In addendum, responses from the interviewees were also analysed to complement the quantitative data analysed through questionnaire administration on the way collaborative governance can be improved to enhance the implementation of the malaria programme in the study area. The malaria coordinator, project manager and programme officers at federal, state and local governments interviewed submitted that financial allocation should be channeled for the purpose of malaria programme to support the funds from partners and donors, as this will help the lower level of governments on the affordability of strategies to eliminate malaria without any reliance on the higher level of government. As revealed by local government malaria officers in 6 out of 9 LGAs covered, adoption of bottom-up approaches (i.e. from local government to state, and to the federal government) will go a long way in the implementation of malaria programme. They projected it attainment through community health officers since local government is closer to the people than other levels of government.

Most interviewees at both the states and LGAs are of similar view as they expressed their opinion by asserting that:

effective communication and openness among all levels of governments will enhance the effort to eliminate malaria, improve in advocacy programme as well as capacity building, focusing on adequate and qualified health workers. Harmonisation of relationships towards achieving vector management by deploying all re s o u r c s w it hout marginalisation of any level of government. Furthermore, collaborative research involving all the levels of health officers to understand the resistance of malaria parasite to the antimalaria drugs and to reduce the prevalence of mortality caused by malaria. (Interview Response, Field Survey, 2018)

\section{DISCUSSION}

The findings revealled the way collaborative governance can be improved to enhance malaria elimination programme. In line with the assertion set out to investigate the objective, it was revealed that if funds allocation to the state and local government is increased, malaria prevention/elimination interventions programme in both urban and rural communities will be enhanced. It is not an understatement that the financial allocation to the health sector, in general, is not encouraging; there has not been any statutory allocation of fund specifically for malaria elimination programme. Finance for malaria programme has been from the little allocation given to the health sector and aids from local and international donors. It is also unfortunate that the majority of external and domestic funds allocated to the health sector through budgetary allocation for malaria intervention hardly get to the target layers captured during budget implementation. Most of these funds get misappropriated, embezzled and squandered by corrupt officials and their collaborating partners (20). However, the qualitative findings established that if the financial allocation is increased and specifically channeled for malaria programme, to complement the financial assistance from partners and donors, the lower level of government could conveniently afford all the strategic plans to control/eliminate malaria without any reliance on the higher level of governments.

The quantitative analysis reveals that an effective referral system on complicated malaria cases from primary to secondary, and to tertiary healthcare facilities is one of the ways to improve inter-governmental collaboration. The study advocates for effective referral system to improve the collaboration among the levels of government considering the fact that, currently, there is weak referral system in the Nigerian health sector. This weak system is militating against the quality of care for severe malaria cases. Therefore, there is a need to improve and expand the existing referral systems as posited by $\mathrm{FMOH}$ and most specifically for severe malaria related cases (21).

The findings of the quantitative analysis on adequate and qualified health workers with unified and indiscriminate salary structure to all levels of health personnel provide justification for the study implication, where the number of the health workforce in Nigeria is not commensurate with the population size as well as the nature of healthcare requirements (22). Some 
of the factors affecting the considerable even distribution of human resource for health in Nigeria are uneven development; quality and quantity of health infrastructure; the number of health workers with their workload; salaries; and remuneration (23). The quantity and quality of health workers are relatively associated with the standard of healthcare facilities, and the nature of healthcare service provisions (24). Hence, just like in the developed countries, there should be sufficient and qualified health workers; discrimination of salaries and other remunerations of health workers at all levels must be curtailed and adequate training for versatility by health workers will go a long way in improving collaborative governance for health development programmes. Moreover, the findings of the study showed that integrated decision making is one of the ways by which inter-governmental collaboration can be improved to enhance the implementation of the malaria programme. This implies unmarginalised and unified decision-making structure, powered by the central to states and to local governments, to achieve the goals and objectives of government on malaria programme and for the benefit of entire citizens.

\section{CONCLUSION}

The findings pointed out that the collaborative involvement by the federal, state and local government is essential, and thereby established that for effective and efficient malaria control/elimination intervention, integrated sustainable decision making should be applied, where all the stakeholders will be involved and actively participate in malaria intervention programmes in order to address the rate of maternal and child death caused by malaria prevalence.

It is therefore recommended that;

1. Collaborative governance should be intensified towards the sustainability of the implementation strategies.

2. There should be a conscious and collective effort by all tiers of government to look inward on how to sustain the ongoing malaria elimination programme.

3. The higher level of government should give financial support to the lower levels for effective implementation of health programmes.

4. All essential malaria interventions strategies like vector control, chemoprevention, diagnostic testing and treatment should be decentralized to cover all populations at risk.

5. Adequate financial aid should be made available for malaria programme, especially the malaria elimination unit at the local levels of government.

6. An intergrated strategies should be adopted. This will accommodate public private partnership and enhance the implementation approach in term of sensitization programme and materials distribution to all the nooks and cranny of the country.

Acknowledgements: The authors will like to acknowledge the contributions of Deputy Programme Manager, Osun State Malaria Elimination Programme, Ministry of Health, Osogbo; Malaria Programme Manager, Department of Public Health, Ogun State Ministry of Health and Malaria Programme Manager, Department of Public Health, Ondo State Ministry of Health. We also acknowledge the effort of all research assistants for their support during data collection in the nine local governments.

Conflicts of interest: The authors declare that there are no competing interests what so ever.

\section{REFERENCES}

1. Koce, F., Randhawa, $G$ and Ochieng, B. Understanding healthcare self-referral in Nigeria from the service users' perspective: a qualitative study of Niger state. 2019, BMC Health Services Research, 19(209): 2-14

2. The Constitution Federal Republic of Nigeria. (1999):130-134

3. National Health Act. Government Notice No. 208. The Federal Republic of Nigeria. Official Gazette 101.2014, Abuja, Nigeria. 139-172

4. Happi, C. T., Gbotosho, G. O., Sowunmi, A., Falade, C. O., Akinboye, D. O. \& Gerena, L. et al. Molecular analysis of Plasmodium falciparum recrudescent malaria infections in children treated with chloroquine in Nigeria. Am. J. Trop. Med. Hyg, 2004, 70(1):20-26.

5. Alliance for Health Policy and Systems Research (AHPSR). Policy Document on Primary Care Systems Profiles and Performance (PRIMASYS), 2015. Abuja, Nigeria: 4-5

6. WHO. Primary Care Systems Profiles \& Performance (Primasys): Nigeria Case Study. The Alliance for Health Policy and Systems Research. Geneva, Switzerland, 2016.

7. FMOH. Nigeria National Council on Health communique. 2009, Abuja, Nigeria: 34-42

8. FMOH. National Guidelines and Strategies for 
Malaria Prevention and Control During Pregnancy. 2014, Second Edition, Abuja Nigeria: 23-24

9. Aribodor, D. N., Ugwuanyi, I. K. \& Aribodor, O. B. Challenges to Achieving Malaria Elimination in Nigeria. ajphr, 2016, 4(1):38-41.

10. Federal Republic of Nigeria. Nigeria Malaria Indicator Survey 2015 Final Report: 3-5

11. USAID. Assessment of Malaria Interventions in Four Nigerian States. Final Report; Measure Evaluation, University of North Carolina at Chapel Hill, 2017:2-4

12. Chukwuocha, U. M. Malaria Control in Nigeria. Primary Healthcare 2012, 2:118. doi:10.4172/2167-1079.1000118.

13. 13. Federal Ministry of Health. Roll Back Malaria Partnership. Focus on Nigeria: Progress and Impact Series. 2012, Country Report: 16-17

14. Federal Ministry of Health. National Malaria Elimination Programme (NMEP) and the Roll Back Malaria Partnership. National Malaria Strategic Plan 2014-2020. 2014, Abuja, Nigeria.

15. Federal Ministry of Health. National Guidelines for Diagnosis and Treatment of Malaria: National Malaria and Vector Control Division. 2015, Abuja, Nigeria. 3rd Edition

16. Malaria Operational Plan FY. President's Malaria Initiative Nigeria. 2016, Annual Report. 12-15

17. National Malaria Control Programme (NMCP). Support to National Malaria Programme in Nigeria (SuNMaP). World Health Organisation (WHO) and the INFORM Project. A Description of the Epidemiology of Malaria to Guide Planning of Control in Nigeria. November 2013.

18. Oluwagbemi, O, Ojutalayo, T \& Obinna, N. Development of a Secured Information System to Manage Malaria Related Cases in the South Western region of Nigeria. ECS Journal, 2010, 34(5):23-34

19. Sicuri, E., Vieta, A., Lindner, L., Constenla, D. and Sauboin, C. The economic costs of malaria in children in three sub-Saharan countries: Ghana, Tanzania and Kenya, Mal J, 2013, 12(307): 2-14

20. 20. Hemingway, J., Shretta, R., Wells, T. N. C., Bell, D., Djimdé, A. A. \& Achee, N. Tools and Strategies for Malaria Control and Elimination: What Do We Need to Achieve a $G$ r a $n$ d Convergence in Malaria? PLoS Biol, 2016, 14(3):1-14

21. Eme, O. I., Uche, O. A. \& Uche, I. B. Building a Solid Healthcare System in Nigeria: Challenges and Prospects. AJIS, 2014, 3(6). 501-510

22. FMOH. Strategic Plan 2009-2013. A Road Map for Malaria Control in Nigeria. 2008, Abuja, Nigeria:17-21

23. Omoluabi, E. Needs Assessment for the Nigerian Health Sector: Promoting Better Management of Migration in Nigeria. International Organisation for Migration. 2014, Abuja, Nigeria:1-62

24. FRN. National Human Resources for Health Strategic Plan 2008 to 2012. A Draft. 2007, Abuja, Nigeria.http://www.who.int/workforcealliance/c ountries/Nigeria_HRHStrategicPlan_2008_2012. pdf

How to cite this article:

Taleat BA., Olawoyin KW. Collaborative governance: The antidote for effective implementation of malaria elimination programme in Nigeria. Research Journal of Health Sciences, 2021, 9(4): 389-398 
Table. 1 Demographic Data of Respondents'

\begin{tabular}{|c|c|c|c|}
\hline Variables & Frequency & Percent & Cumulative Percent \\
\hline \multicolumn{4}{|l|}{ Gender } \\
\hline Male & 138 & 38.0 & 38.0 \\
\hline Female & 225 & 62.0 & 100.0 \\
\hline Total & 363 & 100.0 & \\
\hline \multicolumn{4}{|l|}{ Age } \\
\hline Below 20years & 15 & 4.1 & 4.1 \\
\hline $21-30$ years & 130 & 35.8 & 39.9 \\
\hline $31-40$ years & 129 & 35.5 & 75.4 \\
\hline $41-50$ years & 72 & 19.8 & 95.2 \\
\hline 51 years and above & 17 & 4.7 & 100.0 \\
\hline Total & 363 & 100.0 & \\
\hline \multicolumn{4}{|l|}{ Marital Status } \\
\hline Single & 135 & 37.2 & 37.2 \\
\hline Married & 224 & 61.7 & 98.9 \\
\hline Divorced & 4 & 1.1 & 100.0 \\
\hline Total & 363 & 100.0 & \\
\hline \multicolumn{4}{|l|}{ Educational Qualification } \\
\hline None & - & - & - \\
\hline School Leaving Certificate & 2 & 0.6 & 0.6 \\
\hline Secondary & 6 & 1.7 & 2.3 \\
\hline Post-Secondary & 61 & 16.8 & 19.1 \\
\hline First Degree & 242 & 66.7 & 85.8 \\
\hline Post-Graduate Degrees & 52 & 14.3 & 100.0 \\
\hline Total & 363 & 100.0 & \\
\hline \multicolumn{4}{|c|}{ Years of Working Experience } \\
\hline Below 5 years & 162 & 44.4 & 44.4 \\
\hline $6-15$ years & 146 & 40.2 & 84.6 \\
\hline $16-25$ years & 43 & 11.8 & 96.4 \\
\hline $26-35$ years & 13 & 3.6 & 100.0 \\
\hline Total & 363 & 100.0 & \\
\hline \multicolumn{4}{|l|}{ Staff Category } \\
\hline Junior Staff & 141 & 38.8 & 38.8 \\
\hline Senior Staff & 195 & 53.7 & 92.5 \\
\hline Contract & 27 & 7.4 & 100.0 \\
\hline Total & 363 & 100.0 & \\
\hline
\end{tabular}

Source: Field Survey, 2018 
Table 2: The Way Collaborative Governance can be improved to enhance the Implementation Malaria Elimination Programme in Southwestern Nigeria

\begin{tabular}{|c|c|c|c|c|c|c|}
\hline & $\begin{array}{l}\text { Strongly } \\
\text { Agree }\end{array}$ & Agree & Undecided & Disagree & $\begin{array}{l}\text { Strongly } \\
\text { Disagree }\end{array}$ & $\begin{array}{l}\text { No } \\
\text { Response }\end{array}$ \\
\hline Assertions & $\begin{array}{l}\mathrm{f} \\
(\%)\end{array}$ & $\begin{array}{l}f \\
(\%)\end{array}$ & $\begin{array}{l}\mathrm{f} \\
(\%)\end{array}$ & $\begin{array}{l}\mathrm{f} \\
(\%)\end{array}$ & $\begin{array}{l}f \\
(\%)\end{array}$ & $\begin{array}{l}\mathrm{f} \\
(\%)\end{array}$ \\
\hline $\begin{array}{l}\text { Increased allocation of } \\
\text { funds for both state and } \\
\text { local government will } \\
\text { enhance malaria } \\
\text { prevention/elimination } \\
\text { interventions in urban and } \\
\text { rural households }\end{array}$ & $\begin{array}{l}253 \\
(69.7)\end{array}$ & $\begin{array}{l}79 \\
(21.8)\end{array}$ & $\begin{array}{l}15 \\
(4.1)\end{array}$ & $\begin{array}{l}3 \\
(0.8)\end{array}$ & $\begin{array}{l}4 \\
(1.1)\end{array}$ & $\begin{array}{l}9 \\
(2.5)\end{array}$ \\
\hline $\begin{array}{l}\text { Availability of appropriate } \\
\text { anti-malaria medicines } \\
\text { and commodities at all } \\
\text { levels of healthcare } \\
\text { services }\end{array}$ & $\begin{array}{l}270 \\
(74.4)\end{array}$ & $\begin{array}{l}75 \\
(20.7)\end{array}$ & $\begin{array}{l}4 \\
(1.1)\end{array}$ & $\begin{array}{l}4 \\
(1.1)\end{array}$ & $\begin{array}{l}4 \\
(1.1)\end{array}$ & $\begin{array}{l}6 \\
(1.7)\end{array}$ \\
\hline $\begin{array}{l}\text { Establishment of several } \\
\text { anti-malaria programmes } \\
\text { targeted towards the } \\
\text { improvement of the } \\
\text { quality of life of the people } \\
\text { by all levels of } \\
\text { government }\end{array}$ & $\begin{array}{l}213 \\
(58.7)\end{array}$ & $\begin{array}{l}116 \\
(32)\end{array}$ & $\begin{array}{l}13 \\
(3.6)\end{array}$ & $\begin{array}{l}3 \\
(0.8)\end{array}$ & $\begin{array}{l}15 \\
(4.1)\end{array}$ & $\begin{array}{l}3 \\
(0.8)\end{array}$ \\
\hline $\begin{array}{l}\text { Effective referral system } \\
\text { on complicated malaria } \\
\text { cases from tertiary to } \\
\text { secondary and secondary } \\
\text { to primary healthcare } \\
\text { facilities }\end{array}$ & $\begin{array}{l}164 \\
(45.2)\end{array}$ & $\begin{array}{l}93 \\
(25.6)\end{array}$ & $\begin{array}{l}30 \\
(8.3)\end{array}$ & $\begin{array}{l}28 \\
(7.7)\end{array}$ & $\begin{array}{l}41 \\
(11.3)\end{array}$ & $\begin{array}{l}7 \\
(1.9)\end{array}$ \\
\hline $\begin{array}{l}\text { Adequate and qualified } \\
\text { health workers with } \\
\text { unified and indiscriminate } \\
\text { salary structure to all } \\
\text { levels of health personnel }\end{array}$ & $\begin{array}{l}129 \\
(35.5)\end{array}$ & $\begin{array}{l}158 \\
(43.5)\end{array}$ & $\begin{array}{l}28 \\
(7.7)\end{array}$ & $\begin{array}{l}13 \\
(3.6)\end{array}$ & $\begin{array}{l}22 \\
(6.1)\end{array}$ & $\begin{array}{l}13 \\
(3.6)\end{array}$ \\
\hline $\begin{array}{lr}\text { Eradication } & \text { of } \\
\text { marginalization at all } \\
\text { levels of government }\end{array}$ & $\begin{array}{l}163 \\
(44.9)\end{array}$ & $\begin{array}{l}111 \\
(30.6)\end{array}$ & $\begin{array}{l}4 \\
(1.1)\end{array}$ & $\begin{array}{l}54 \\
(14.9)\end{array}$ & $\begin{array}{l}27 \\
(7.4)\end{array}$ & $\begin{array}{l}4 \\
(1.1)\end{array}$ \\
\hline $\begin{array}{l}\text { Harmonization of } \\
\text { relationships among health } \\
\text { workers at all levels of } \\
\text { healthcare delivery }\end{array}$ & $\begin{array}{l}203 \\
(55.9)\end{array}$ & $\begin{array}{l}124 \\
(34.2)\end{array}$ & $\begin{array}{l}18 \\
(5)\end{array}$ & - & $\begin{array}{l}4 \\
(1.1)\end{array}$ & $\begin{array}{l}14 \\
(3.9)\end{array}$ \\
\hline $\begin{array}{ll}\text { Integrated } & \text { decision } \\
\text { making process } & \end{array}$ & $\begin{array}{l}213 \\
(58.7)\end{array}$ & $\begin{array}{l}104 \\
(28.7)\end{array}$ & $\begin{array}{l}24 \\
(6.6)\end{array}$ & $\begin{array}{l}15 \\
(4.1)\end{array}$ & $\begin{array}{l}4 \\
(1.1)\end{array}$ & $\begin{array}{l}3 \\
(0.8)\end{array}$ \\
\hline
\end{tabular}

Source: Field Survey, $20 \overline{18 .}$ NB: $f=$ Frequency; $\%=$ Percentage 